Working Paper/Document de travail

2007-21

\title{
A No-Arbitrage Analysis of Macroeconomic Determinants of Term Structures and the Exchange Rate
}

by Fousseni Chabi-Yo and Jun Yang 
Bank of Canada Working Paper 2007-21

March 2007

\title{
A No-Arbitrage Analysis of Macroeconomic Determinants of Term Structures and the Exchange Rate
}

\author{
by \\ Fousseni Chabi-Yo and Jun Yang \\ Financial Markets Department \\ Bank of Canada \\ Ottawa, Ontario, Canada K1A 0G9 \\ fchabiyo@bankofcanada.ca \\ junyang@bankofcanada.ca
}

Bank of Canada working papers are theoretical or empirical works-in-progress on subjects in economics and finance. The views expressed in this paper are those of the authors.

No responsibility for them should be attributed to the Bank of Canada. 


\begin{abstract}
We study the joint dynamics of macroeconomic variables, bond yields, and the exchange rate in an empirical two-country New-Keynesian model complemented with a no-arbitrage term structure model. With Canadian and US data, we are able to study the impact of macroeconomic shocks from both countries on their yield curves and the exchange rate. The variance decomposition of the yield level shows that the US monetary policy and aggregate supply shocks explain a majority of the unconditional variations in Canadian yields. They also explain up to 50\% of the variations in the expected excess holding period returns of Canadian bonds. In addition, Canadian monetary policy shocks explain more than $70 \%$ of the variations in Canadian yields over short and medium forecast horizons. It also explains around $40 \%$ of the expected excess holding period returns of Canadian bonds. Both Canadian and US macroeconomic shocks help explain the dynamics of the exchange rate and the time-varying exchange risk premium.

JEL classification: E12, E43, F41, G12, G15

Bank classification: Debt management; Exchange rates; Interest rates; Financial markets;

Econometric and statistical methods
\end{abstract}

\title{
Résumé
}

Les auteurs étudient la dynamique combinée des variables macroéconomiques, des rendements obligataires et du taux de change dans le cadre d'un nouveau modèle keynésien empirique à deux pays, enrichi d'un modèle de structure des taux d'intérêt sans possibilités d'arbitrage. À partir de données canadiennes et américaines, ils analysent l'incidence des chocs macroéconomiques observés au Canada et aux États-Unis sur les courbes de rendement et le taux de change. La décomposition de la variance des rendements révèle que les chocs d'offre globale et de politique monétaire survenus aux États-Unis permettent de rendre compte de la majorité des variations non conditionnelles des rendements canadiens. Ces chocs permettent également d'expliquer jusqu'à $50 \%$ des fluctuations des rendements excédentaires attendus sur la durée de détention des obligations canadiennes. Par ailleurs, les chocs de politique monétaire au Canada sont à l'origine de plus de $70 \%$ des variations des rendements canadiens aux horizons de court et moyen terme et d'environ $40 \%$ des rendements excédentaires attendus sur la durée de détention des obligations canadiennes. Les chocs macroéconomiques constatés au Canada et aux États-Unis aident ensemble à expliquer la dynamique du taux de change et de la prime de risque de change variable dans le temps.

Classification JEL : E12, E43, F41, G12, G15

Classification de la Banque : Gestion de la dette; Taux de change; Taux d'intérêt; Marchés financiers; Méthodes économétriques et statistiques 


\section{Introduction}

This paper investigates the economic determinants of the movements of the term structures of interest rates and the exchange rate between a small open economy (SOE) and a closed foreign economy. We introduce an empirical new-Keynesian model to study the dynamics of macroeconomic variables in both countries. Then we incorporate the macro variables as factors in a two-country term structure model derived under no-arbitrage conditions. This setting enables us to study the joint dynamics of the bond yields and the exchange rate. We implement the macro-finance modeling strategy with data from Canada (a proxy for the SOE) and the US (a proxy for the closed foreign economy). The variance decomposition results show that US monetary policy and aggregate supply shocks contribute to a majority of the unconditional variations in Canadian yields. In addition, all three US macro shocks contribute around 50\% of the variations in the expected excess returns of holding Canadian bonds for one quarter at various forecast horizons. Furthermore, Canadian monetary policy shocks are the dominate factor in explaining the variations in Canadian yields over short and medium-forecast horizons. It also explains around $40 \%$ of the variations in the expected excess holding period returns of Canadian bonds. Finally, the macro factors in both countries seem to play important roles in explaining the exchange rate dynamics and the exchange risk premium.

We propose an empirical new-Keynesian model to describe the dynamics of macro variables in two countries. In each country, the macroeconomic model comprises an

aggregate supply (AS) equation, an aggregate demand (IS) equation, and a forward looking monetary policy rule (e.g. Cho and Moreno (2006), and Clarida, Gali, and Gertler (1999)). In addition, the aggregate supply and the aggregate demand shocks from the closed economy are allowed to pass through in the SOE, but not vice versa. These assumptions impose a number of cross-equation restrictions on the model, and 
allow us to identify the country specific macro shocks from the SOE.

Then we construct a two-country term structure model using a factor representation for the stochastic discount factor (SDF), coupled with flexible time-varying risk premia. In the SOE, the SDF is driven by both domestic and foreign macroeconomic shocks. In the closed foreign economy, the SDF is driven entirely by its domestic macroeconomic shocks. In this framework, we can separate the impact of the SOE macro shocks on its yield curve from that of the foreign macro shocks. In addition, the setup directly links the exchange rate dynamics to those of the SDFs. It allows us to investigate the dynamics of the exchange rate and its relationship to macroeconomic shocks from both countries. The movements of bond yields and the exchange rate rule out arbitrage opportunities in bond and exchange rate markets.

We estimate the model with Canadian and US data from 1980 to 2006 using the maximum likelihood estimation technique. Our main findings are as follows. First, US macroeconomic shocks are important in explaining the dynamics of Canadian yields. The US monetary policy and aggregate supply shocks explain $64 \%, 60 \%$ and $50 \%$ of the unconditional variations in the Canadian 1-year, 5-year and 15-year yields respectively. Canadian monetary policy shocks are the dominate factor in explaining the variations in Canadian yields over short- and medium-forecast horizons. It explains more than $85 \%$ and $76 \%$ of the variations of Canadian yields at 1-quarter and 4-quarter forecast horizons respectively. US monetary policy shocks are the dominate factor in explaining more than $70 \%$ of the variations in US yields across maturities and at various forecast horizons. US aggregate supply shocks explains over $20 \%$ of the unconditional variations in US yields, and $10-25 \%$ of the variations in the expected excess holding period returns.

Second, all three US macro variables contribute around $50 \%$ of the variations in the expected excess holding period returns of Canadian bonds. Therefore, they are important in explaining time-varying risk premia embedded in Canadian bonds. Canadian monetary 
policy shocks are the most significant one among the different Canadian macroeconomic shocks, and they explain about $40 \%$ of the variations in the expected excess holding period returns of Canadian bonds. US monetary policy shocks are the dominate factor in explaining more than $70 \%$ of the variations in the expected excess holding period returns of US bonds.

Third, both US and Canadian macroeconomic shocks help explain the dynamics of the exchange rate between Canada and US. We find that the correlation between the modelimplied depreciation rate and that computed from the data is $21 \%$, and the correlation between the model-implied exchange risk premium and its counterpart from the data is $25 \%$.

This paper is related to several branches of literature. The first is the empirical VAR studies of the dynamics of macro variables, government bond yields, and exchange rate (e.g. Estrella and Hardouvelis (1991), Estrella and Mishkin (1997), and Evans and Marshall (1998)). In contrast to empirical VAR studies our model is able to explain the whole yield curve, not only yields included in a VAR. In addition, we are able to study risk premia embedded in long yields and the exchange rate in the context of a no-arbitrage model with a flexible specification of market prices of risk rather than relying on assumptions of the expectations hypothesis and uncovered interest rate parity. The second line of literature is the work that incorporates observable macroeconomic variables in term structure models ${ }^{1}$. This paper is a natural extension of the literature from a one-country setting to a two-country setting. Our framework allows us to study the impacts of both domestic and foreign macroeconomic shocks on yield curves. Finally, this paper is related to the literature studying the exchange rate dynamics using two-country term structure

\footnotetext{
${ }^{1}$ These works include Ang and Piazzesi (2003), An, Dong, and Piazzesi (2005), Bakaert, Cho, and Moreno (2005), Bikbov and Chernov (2005), Diebold, Rudebusch, and Arouba (2005), Duffee (2005), Gallmeyer, Hollifield, and Zin (2005), Garcia and Luger (2006), Hördahl, Tristani, and Vestin (2004), and $\mathrm{Wu}(2002)$ among others.
} 
models of interest rates ${ }^{2}$. Most of these studies use latent factors to explain the dynamics of yield curves and exchange rates. Moreover, they leave unanswered the question of what macroeconomic fundamentals drive the variations in yields, exchange rates and embedded risk premia. We intend to investigate the macroeconomic determinants of those latent factors and provide an economic interpretation.

This paper is similar to Dong (2006) which studies the role of macro variables in explaining the foreign exchange risk premium and the dynamics of exchange rates. While Dong uses a structural VAR to model the joint dynamics of the macroeconomic variables, we use an empirical New-Keynesian model to identify the macroeconomic shocks. Dong (2006) concentrates his study on explaining the foreign exchange risk premium. We investigate the macroeconomic determinants of the risk premia embedded in yields and the exchange rate. In addition, latent factors combined with macro variables are used in Dong (2006) to fit yield curves and the exchange rate. The underlying variables in our study are all observable. Finally, we estimate our model with Canadian/US data, while Dong uses German/US data.

The rest of the paper is organized as follows. Section 2 outlines the model and describes how to price bonds and the exchange rate under no-arbitrage conditions. Section 3 discusses the data and the estimation technique. Section 4 presents findings, and Section 5 concludes.

\section{The Model}

We propose an empirical macro model inspired by the new-Keynesian macroeconomic literature (Clarida, Gali, and Gertler (1999)). In these models, an economy is represented by a core structure consisting of an aggregate supply equation (a Phillips curve), an

\footnotetext{
${ }^{2}$ See Ahn (2004), Amin and Jarrow (1991), Graveline (2006), Han and Hammond (2003), Leippold and Wu (2004), Nielsen and Saa-Requejo (1993) among others.
} 
aggregate demand equation (an IS/AD equation), and a monetary policy rule for setting a short-term interest rate (the policy instrument). For closed economies, these models imply a dynamic system among inflation, the output gap, and the short-term interest rate. In open economies, each equation may include the exchange rate and foreign variables. In our two-country model, we assume that one country is a closed economy and the other one is a SOE in the sense that the macroeconomic shocks from the closed economy affect the SOE, but not vice-versa.

\subsection{Closed Economy Macro Model}

In the closed economy, we assume that the macroeconomic fundamentals are captured by a set of state variables $\left(\pi_{t}^{*}, g_{t}^{*}, r_{t}^{*}\right)$, where $\pi_{t}^{*}$ is inflation, $g_{t}^{*}$ is the output gap, and $r_{t}^{*}$ is the short-term interest rate. We denote the variables in the closed economy with an asterisk. The evolution of the state variables is described by the following model (e.g. Cho and Moreno (2006)),

$$
\begin{aligned}
& \pi_{t}^{*}=\alpha_{0}^{*}+\alpha_{\pi}^{*} E_{t} \pi_{t+1}^{*}+\left(1-\alpha_{\pi}^{*}\right) \pi_{t-1}^{*}+\alpha_{g}^{*} g_{t}^{*}+\varepsilon_{\pi t}^{*}, \\
& g_{t}^{*}=\beta_{0}^{*}+\beta_{g}^{*} E_{t} g_{t+1}^{*}+\left(1-\beta_{g}^{*}\right) g_{t-1}^{*}+\beta_{r}^{*}\left(r_{t}^{*}-E_{t} \pi_{t+1}^{*}\right)+\varepsilon_{g t}^{*}, \\
& r_{t}^{*}=\gamma_{0}^{*}+\left(1-\rho^{*}\right)\left(\gamma_{\pi}^{*} E_{t} \pi_{t+1}^{*}+\gamma_{y}^{*} g_{t}^{*}\right)+\rho^{*} r_{t-1}^{*}+\varepsilon_{r t}^{*} .
\end{aligned}
$$

The aggregate supply (AS) equation (1) describes the supply side of the economy. It links inflation to expected future inflation and the real marginal cost with an assumption that the output gap is proportional to the marginal cost. In the presence of price stickiness, higher expected inflation will lead to higher prices today. The aggregate demand (AD) equation (2) postulates that the current output depends on lagged and expected output and on the real interest rate. Higher expected output leads to higher consumption today, 
and higher consumption today raises the current aggregate demand. Equation (3) represents a monetary policy rule (MP) where the monetary authority sets the short-term interest rate according to Clarida, Gali, and Gertler (2000). The monetary policy rule has the form of a forward-looking Taylor rule that allows some degree of monetary policy inertia captured by the smoothing parameter $\rho^{*}$. The lagged interest rate captures the well known tendency of the monetary authority towards smoothing interest rates. The monetary authority systematically reacts to the expected future inflation and to the deviation of output from its trend. We refer to $\varepsilon_{\pi t}^{*}$, $\varepsilon_{g t}^{*}$, and $\varepsilon_{r t}^{*}$ as the aggregate supply shock, the aggregate demand shock, and the monetary policy shock respectively. These shocks are assumed to be i.i.d normal disturbances.

\subsection{Small Open Economy Macro Model}

In the SOE, the joint dynamics of the same set of state variables is captured by a model which is slightly different from that of the closed economy

$$
\begin{aligned}
& \pi_{t}=\alpha_{0}+\alpha_{\pi} E_{t} \pi_{t+1}+\left(1-\alpha_{\pi}\right) \pi_{t-1}+\alpha_{g} g_{t}+\alpha_{\pi_{t}^{*}} \pi_{t}^{*}+\alpha_{\pi_{t-1}^{*}} \pi_{t-1}^{*}+\varepsilon_{\pi t} \\
& g_{t}=\beta_{0}+\beta_{g} E_{t} g_{t+1}+\left(1-\beta_{g}\right) g_{t-1}+\beta_{r}\left(r_{t}-E_{t} \pi_{t+1}\right)+\beta_{g_{t}^{*}} g_{t}^{*}+\beta_{g_{t-1}^{*}} g_{t-1}^{*}+\varepsilon_{g t} \\
& r_{t}=\gamma_{0}+(1-\rho)\left(\gamma_{\pi} E_{t} \pi_{t+1}+\gamma_{g} g_{t}\right)+\rho r_{t-1}+\varepsilon_{r t} .
\end{aligned}
$$

In the aggregate supply equation (4), we allow a direct pass through of current and lagged foreign aggregate supply shocks. In the aggregate demand equation (5), we also allow a direct pass through of current and lagged foreign aggregate demand shocks. In most open economy macro models, foreign aggregate supply and demand shocks are allowed to pass through an additional exchange rate channel. The dynamics of the exchange rate are usually described by the uncovered interest rate parity (UIRP) (i.e. no foreign 
exchange risk premium), or the UIRP plus an exogenous exchange risk premium. We intend to study the economic determinants of the dynamics of yield curves, the exchange rate and their embedded risk premia. An assumption of either the UIRP or the UIRP plus an exogenous exchange risk premium is inappropriate. Allowing the impact of exchange rate changes on the aggregate supply and the aggregate demand in a SOE, combined with an endogenous exchange risk premium, complicates the process of finding a rational expectation solution to our macro model. We leave it for future research. Equation (6) represents a monetary policy rule in the SOE. We assume that it has the same specification as in the closed economy. The aggregate supply shock, the aggregate demand shock, and the monetary policy shock $\varepsilon_{t}^{\pi}, \varepsilon_{t}^{y}$, and $\varepsilon_{t}^{r}$ are assumed to be i.i.d normal disturbances.

The dynamics of the macro fundamentals, $X_{t}=\left(\pi_{t}, g_{t}, r_{t}, \pi_{t}^{*}, g_{t}^{*}, r_{t}^{*}\right)$, in our twocountry model are described by equation (1) to (6). We can summarize the macro model in a matrix form,

$$
A_{11} X_{t}=B_{0}+B_{11} E_{t} X_{t+1}+B_{12} X_{t-1}+\varepsilon_{t}
$$

where the coefficients of matrix $A_{11}, B_{11}$ and $B_{12}$ are defined by equations (1) to (6). A solution to the rational expectation model based on the Schur decomposition can be obtained numerically by standard methods (e.g. McCallum (1998), and Söderland (1999)). The solution can be written as the following reduced form,

$$
X_{t}=\mu+\Phi X_{t-1}+\Sigma \varepsilon_{t}
$$

The reduced form macro dynamics are essentially a $\operatorname{VAR}(1)$ process with non-linear restrictions on its parameter matrices. In addition, the assumption of one closed economy and one SOE in the model implies that the left lower off-diagonal matrices of $\Phi$ and $\Sigma$ 
are zeros.

\subsection{Stochastic Discount Factor}

The system (8) expresses the short-term interest rates of both countries as linear functions of the state vector $X_{t}$, which follows a first-order Gaussian VAR. More precisely, we can express the short-term interest rate in country $i$ as

$$
r_{t}^{(i)}=\delta_{0}^{(i)}+\delta_{1}^{(i) \mathrm{T}} X_{t}
$$

where $\delta_{1}^{(i)}=[0,0,1,0,0,0]^{\mathrm{T}}$ in the SOE and $\delta_{1}^{(i)}=[0,0,0,0,0,1]^{\mathrm{T}}$ in the closed economy. The assumption of one SOE and one closed economy in our model implies that macro shocks from both countries drive the dynamics of the yield curve in the SOE, while only the macro shocks from the closed economy affect the yield curve in the closed economy.

Our specification is the standard affine term structure setting. We follow the dynamic arbitrage-free term structure literature and define the nominal stochastic discount factor in country $i$ as

$$
m_{t+1}^{(i)}=\exp \left(-r_{t}^{(i)}-\frac{1}{2} \lambda_{t}^{(i) \mathrm{T}} \lambda_{t}^{(i)}-\lambda_{t}^{(i)^{\prime}} \varepsilon_{t+1}^{(i)}\right)
$$

where $r_{t}^{(i)}$ is the short-term interest rate, and $\lambda_{t}^{(i)}$ is the market price of risk associated with the source of uncertainty, $\varepsilon_{t+1}^{(i)}$, in the economy. The market price of risk is assumed to be proportional to the factor volatilities in standard affine term structure models (Dai and Singleton (2000)), which implies a constant risk premium in our Gaussian setting. However, recent empirical studies (e.g. Duffee (2002), and Dai and Singleton (2002)) have highlighted the benefits in allowing for a more flexible specification of the market 
price of risk. We follow their approach and specify $\lambda_{t}^{(i)}$ as a linear function of $X_{t}$

$$
\lambda_{t}^{(i)}=\lambda_{0}^{(i)}+\lambda_{1}^{(i)} X_{t}
$$

where $\lambda_{0}^{(i)}$ is a $6 \times 1$ vector, and $\lambda_{1}^{(i)}$, is a $6 \times 6$ matrix. This specification allows a time-varying risk premium and relates it to the fundamentals of the economy. It should be pointed out that, in a micro-founded framework, the market price of risk depends on consumer preferences rather than being imposed exogenously. However, this empirically motivated specification gives us the flexibility to match yield dynamics. We parameterize the market prices of risk for the closed economy and the SOE respectively as

$$
\begin{aligned}
& \lambda_{0}^{*}=\left[\begin{array}{c}
0_{3 \times 1} \\
(\cdot)_{3 \times 1}
\end{array}\right] \text { and } \lambda_{1}^{*}=\left[\begin{array}{cc}
0_{3 \times 3} & 0_{3 \times 3} \\
0_{3 \times 3} & (\cdot)_{3 \times 3}
\end{array}\right], \\
& \lambda_{0}=\left[\begin{array}{c}
(\cdot)_{3 \times 1} \\
(\cdot)_{3 \times 1}
\end{array}\right] \text { and } \lambda_{1}=\left[\begin{array}{cc}
(\cdot)_{3 \times 3} & (\cdot)_{3 \times 3} \\
0_{3 \times 3} & (\cdot)_{3 \times 3}
\end{array}\right] .
\end{aligned}
$$

The parameterization of $\lambda_{t}^{(i)}$ implies that the market price of risk in the SOE depends on the macro variables in both countries, and the market price of risk in the closed economy depends entirely on its domestic variables. In addition, the specification for $\lambda_{1}$ implies that, in the SOE, the market price of the SOE risk depends on both the variables of the SOE and the closed economy, and the market price of the foreign risk depends only on foreign variables. The specification of the market prices of risk is consistent with the setup of the macro model. Our parameterization of the market prices of risk also implies that the stochastic discount factors in both countries are correlated, which is one of the major findings of Brandt, Cochrane, and Santa-Clara (2005). 


\subsection{Bond Yields and Expected Returns}

The SDF in country $i$ prices all zero coupon bonds in the economy from the recursive relation:

$$
E_{t}\left(m_{t+1}^{(i)} p_{t+1}^{(i, n-1)}\right)=p_{t}^{(i, n)}
$$

where $p_{t}^{(i, n)}$ is the price of an $n$-period zero coupon bond of country $i$ at time $t$.

Using the above equation recursively, we can compute the yield of an $n$-period zero coupon bond of country $i$ as

$$
y_{t}^{(i, n)}=a_{n}^{(i)}+b_{n}^{(i) \mathrm{T}} X_{t}
$$

The coefficients $a_{n}^{(i)}$ and $b_{n}^{(i)}$ are given by $a_{n}^{(i)}=-A_{n}^{(i)} / n$ and $b_{n}^{(i)}=-B_{n}^{(i)} / n$, where $A_{n}^{(i)}$ and $B_{n}^{(i)}$ follow the difference equations:

$$
\begin{aligned}
& A_{n+1}^{(i)}=A_{n}^{(i)}+B_{n}^{(i) \mathrm{T}}\left(\mu-\Sigma \lambda_{0}^{(i)}\right)+\frac{1}{2} B_{n}^{(i) \mathrm{T}} \Sigma \Sigma^{\mathrm{T}} B_{n}^{(i)}-\delta_{0}^{(i)}, \\
& B_{n+1}^{(i) \mathrm{T}}=B_{n}^{(i) \mathrm{T}}\left(\Phi-\Sigma \lambda_{1}^{(i)}\right)-\delta_{1}^{(i) \mathrm{T}},
\end{aligned}
$$

with $A_{1}^{(i)}=\delta_{0}^{(i)}$ and $B_{1}^{(i)^{\prime}}=\delta_{1}^{(i) \mathrm{T}}$.

The expressions of $a_{n}^{(i)}$ and $b_{n}^{(i)}$ in equation (12) show that $\lambda_{0}^{(i)}$ controls the level of long yields relative to short yields and $\lambda_{1}^{(i)}$ controls the time-varying component of long yields related to the state variables.

Since bond yields are in affine form and the conditional mean of the state variables $X_{t}$ is affine, expected holding period returns on zero coupon bonds are also affine in $X_{t}$. We can express the one-period excess holding period return of an $n$-period bond of country $i$ as

$$
r x_{t+1}^{(i, n)}=\ln \left(\frac{P_{t+1}^{(i, n-1)}}{P_{t}^{(i, n)}}\right)-r_{t}^{(i)}=n y_{t}^{(i, n)}-(n-1) y_{t+1}^{(i, n-1)}-r_{t}^{(i)}
$$


The conditional excess holding period return can be computed as

$$
E_{t}\left[r x_{t+1}^{(i, n)}\right]=A_{n}^{(i, x)}+B_{n}^{(i, x) \mathrm{T}} X_{t}
$$

where $A_{n}^{(i, x)}=-\frac{1}{2} B_{n-1}^{(i) \mathrm{T}} \Sigma \Sigma^{\mathrm{T}} B_{n-1}^{(i)}+B_{n-1}^{(i) \mathrm{T}} \Sigma \lambda_{0}^{(i)}$ and $B_{n}^{(i, x)}=\lambda_{1}^{(i) \mathrm{T}} \Sigma^{\mathrm{T}} B_{n-1}^{(i)}$.

From equation (12) and (13), we can see that both bond yields and the expected excess holding period returns are linear functions of $X_{t}$. Therefore, the variance decompositions can be easily implemented using standard VAR methods.

\subsection{Exchange Rate Dynamics}

The definition of a SDF implies that the SDF in country $i$ can also price another country's zero coupon bonds if we convert the foreign currency into the domestic currency. Let $p_{t}^{(n)}$ denote the price of an $n$-period zero coupon bond of the SOE, the price of the same bond denominated in the foreign currency is $p_{t}^{(n)} / S_{t}$, where $S_{t}$ denotes the nominal exchange rate between the SOE and the closed foreign economy (i.e. the SOE price of one unit of the foreign currency). Under the assumption of no-arbitrage opportunities, we must have

$$
E_{t}\left(m_{t+1}^{*} p_{t+1}^{(n-1)} / S_{t+1}\right)=p_{t}^{(n)} / S_{t}
$$

where $m_{t+1}^{*}$ is the SDF in the foreign country.

If markets are complete, various papers (e.g. Bakaert (1996), Backus, Foresi, and Telmer (2001), and Brandt, and Santa-Clara (2002)) have demonstrated that the following equilibrium condition must hold

$$
\frac{m_{t+1}^{*}}{m_{t+1}}=\frac{S_{t+1}}{S_{t}}
$$

With the definitions for $m_{t+1}$ and $m_{t+1}^{*}$ in equation (9), taking natural logarithms of both 
sides of equation (14) yields the expression of the depreciation rate as

$$
\Delta s_{t+1}=s_{t+1}-s_{t}=r_{t}-r_{t}^{*}+\frac{1}{2}\left(\lambda_{t}^{\mathrm{T}} \lambda_{t}-\lambda_{t}^{* \mathrm{~T}} \lambda_{t}^{*}\right)+\left(\lambda_{t}^{\mathrm{T}}-\lambda_{t}^{* \mathrm{~T}}\right) \epsilon_{t+1},
$$

where $s_{t}$ is the natural logarithm of $S_{t+1}$. From equation (15), the expected change in the exchange rate is equal to the difference, $r_{t}-r_{t}^{*}$, between the domestic and foreign interest rates, plus a risk premium, $\frac{1}{2}\left(\lambda_{t}^{\mathrm{T}} \lambda_{t}-\lambda_{t}^{* \mathrm{~T}} \lambda_{t}^{*}\right)$. For an investor in the SOE, the excess return from investing in foreign bond markets is $s_{t+1}-s_{t}-r_{t}+r_{t}^{*}$. Therefore, the one-period excess return or the foreign exchange risk premium is

$$
r e_{t}=s_{t+1}-s_{t}-r_{t}+r_{t}^{*}=\frac{1}{2}\left(\lambda_{t}^{\mathrm{T}} \lambda_{t}-\lambda_{t}^{* \mathrm{~T}} \lambda_{t}^{*}\right)+\left(\lambda_{t}^{\mathrm{T}}-\lambda_{t}^{* \mathrm{~T}}\right) \epsilon_{t+1} .
$$

It is worth noting that although yields are affine functions of the state variable $X_{t}$, the expected change in the exchange rate is not. In fact, it is a quadratic function of $X_{t}$ because of the term of the nonlinear exchange risk premium. Equation (15) essentially links the risk premia embedded in bond yields of both countries to that embedded in the exchange rate. In a risk-neutral world with $\lambda_{t}=\lambda_{t}^{*}=0$, the UIRP states that the expected change in the exchange rate is equal to the interest rate difference between two countries. However, empirical studies have shown that the UIRP is unlikely to hold. Various latent-factor term structure models have been proposed to study the time-varying exchange risk premium. We try to investigate whether macro shocks help explain the variation in the change in the exchange rate, after taking account of the exchange risk premium. 


\section{Data and Econometric Methodology}

We estimate the model with quarterly macro, yield and exchange rate data from Canada and the US. Canada is used as a proxy for the SOE, and the US is a proxy for the closed foreign economy. There has been a fundamental shift in the way the central banks of Canada and the US conduct monetary policy in the post-war period, which could imply a regime switch in the dynamics of macro variables. We choose a sample period of 1980:Q1 to 2006:Q2, when controlling inflation became a major focus of the central banks in both countries. The macroeconomic variables include inflation, output gaps, and short-term interest rates. The Canadian core CPI index and the US implicit GDP deflator are used to compute inflation ${ }^{3}$. The inflation rate is computed as the log difference of the index between the end and the beginning of each quarter. We measure the output gap as the linearly detrended real GDP. The 3-month Treasury bill rates are used as the monetary policy instruments in both countries ${ }^{4}$. The Canadian macro series are taken from the Statistics of Canada CANSIM database. The US macro series are taken from the St. Louis FED economic database.

To estimate the term structure model, we use continuously compounded zero coupon yields of maturities $2,4,8,12,20,28,40$ and 60 quarters from both countries. The Canadian zero yield curve is constructed by the Bank of Canada (Bolder, Johnson, and Metzler (2004)). The US zero yield curve is constructed by Gurkaynak, Sack, and Wright (2006) at the Federal Reserve Board. Bond yields are sampled at the end of a quarter. All inflation rates, 3-month Treasury bill rates, and bond yields are quarterly rates.

The Canadian Dollar/US Dollar exchange rates are also taken from the Statistics

\footnotetext{
${ }^{3}$ Canadian inflation presents a clear outlier in 1991:Q1 because of the introduction of a value-added tax (i.e. GST). We interpolate this observation using the average of inflation measures in the neighboring quarters.

${ }^{4}$ The actually monetary policy instrument is the over-night rate in Canada and the federal fund rate in the US.
} 
Canada CANSIM database, which are the noon mid-market rates in the last day of a quarter.

We use maximum likelihood to estimate the macro structural parameters and timevarying market prices of risk. Obviously, it is most efficient to estimate all parameters in one step. However, because of the estimation difficulty involved with maximizing in a high dimension, we use a two-step estimation technique. In the first step, we estimate macro structural parameters with both Canadian and US macro data. In the second step, we fix those parameters and estimate market prices of risk with bond yields and the exchange rate. Although we lose some efficiency, the estimates are still consistent.

The likelihood function in the first step is calculated based on the reduced form equation (8). To calculate the likelihood function in the second step, we add measurement errors to the bond yield formula in equation (12) and the depreciation rate equation (15). The setup ensures that the shocks to macro variables in equation (15) enter the depreciation rate. Adding a measurement error to equation (15) avoids the stochastic singularity problem.

\section{Empirical Results}

In this section we present our empirical findings. First we present the parameter estimates in the macro dynamics and the market prices of risk. Then we discuss the fit of the model. In the second part we present the impulse response functions of macro variables to structural shocks, and analyze the variance decompositions of bond yields and expected excess holding period returns. We also present the empirical results on the exchange rate and the exchange risk premium in the second part. 


\subsection{Parameter Estimates}

\subsubsection{Macro Model}

The maximum likelihood estimates are shown in Table 1. The asymptotic standard errors are obtained based on a 3-lag Newey and West (1987) consistent covariance estimator. Our estimation yields a unique stationary solution. Panel A shows the parameter estimates for the two-country macro model.

The first row of Panel A shows the parameter estimates of the Phillips curves of both countries. The Phillips curve parameter estimate for Canada does not have the expected sign, but the sign for the US is as expected. However, both estimates are not statistically significantly different from zero. This reflects the weak link between detrended output and inflation in the data. The finding is consistent with the previous literature. The forward-looking parameters in both AS equations are larger than 0.5, implying a higher degree of forward looking behavior from the agents over the sample period. In addition, the parameter estimates of current and lagged US inflations are statistically significant in the Canadian AS equation. It suggests an inflation pass through across the border.

The second row shows the parameter estimates for the AD equations. The forwardlooking parameters are indistinguishable from 0.5, implying that agents put similar weights on the expected and past output gaps. The real interest rate parameter estimate has the right sign in the Canadian $\mathrm{AD}$ equation, but not in the US AD equation. Neither estimate is statistically significant. The current and lagged US output gap parameter estimates are statistically significant in the Canadian AD equation. This implies that US aggregate demand has a direct impact on Canadian aggregate demand.

The third row of Panel A shows the parameter estimates in the monetary policy rule equations in both countries. The Canadian short rate loads positively on Canadian inflation, and the output gap with coefficients of 1.49 , and 0.10 respectively. The US short 
rate loads positively on US inflation, and the output gap with coefficients of 1.08 , and 0.04 respectively. The results suggests that the monetary authorities in both countries response strongly to shocks which could increase the expected future inflation. A 1 percent increase in the expected inflation leads to 1.49 and 1.08 percent increases in Canadian and US short rates respectively. The interest rate smoothing parameter estimates are above 0.8 in the monetary policy rule equations, reflecting the well known persistence in the short-term interest rates.

Figure 1 presents the model-implied macro variables and shocks. It shows that there are no major Canadian and US AS shocks during the sample period. The Canadian and US AD shocks exhibit some persistence. The monetary policy shocks are of smaller magnitudes in both countries after the mid-1980s.

\subsubsection{Market Prices of Risk}

We report the estimates of the market prices of risk in Panel B of Table 1. In Canada, the market price of risk coefficients corresponding to both domestic and foreign inflations, output gaps, and short-term interest rates are highly significant. This implies that observable Canadian and US macro variables drive time-variation in risk premia of Canadian yields. In addition, the impacts of US variables on the market price of Canadian variables are statistically significant. This suggests that US macro variables play important roles in explaining time-varying risk premia embedded in Canadian yields. Furthermore, in the US, the market price of risk coefficients corresponding to US inflation, output gap, and short-term interest rate are highly significant, implying that the observable US macro variables also drive the time-variation in risk premia embedded in US yields. 


\subsubsection{Fit of the Model}

Table 2 reports the first and second unconditional moments of macro variables, yields, and changes in the exchange rate from the data and implied by the model. We compute standard errors of data moments using GMM with 4 lags. The moments computed from the model are well within two standard deviations from their counterparts in data for both Canadian and US macro variables (Panel A), and bond yields (Panel B). Panel A shows that the model provides an almost exact match with the unconditional first moments to inflation, the output gaps, and short-term interest rates. The model provides smaller unconditional second moments to macro variables than those computed from the data. However, the model-implied estimates are within two standard deviations of the data point estimates.

The model also provides an almost exact match with the unconditional first moments to Canadian and US bond yields. The model-implied unconditional second moments of short-term yields are indistinguishable from their counterparts in the data. The model provides smaller unconditional second moment estimates of long-term yields, although they are still within two standard deviations of the data point estimates. Thus the measurement errors in the long yield equations have bigger variances than those in the short yield equations. This implies that there are variations in long yields unexplained by the macro variables included in the model. The model-implied autocorrelations for bond yields are slightly smaller than those calculated from data.

The model-implied unconditional first and second moments of the depreciation rate of the changes are within two standard deviations of the data point estimates. However, the model-implied autocorrelation is 0.57 , much higher than the 0.033 autocorrelation computed from the data. This is because that the macro variables included in the model are very persistent. 
In general, the model matches unconditional moments of macro variables and bond yields. However, the model generates more persistent estimates for the depreciation rate of the exchange rate than that observed from the data.

\subsection{Macro Dynamics, Term Structures and Exchange Rate}

\subsubsection{Impulse Responses of Macro Variables}

Figure 2 shows the impulse response functions of the macro variables to a one standard deviation increase of each of the structural shocks. The units for the responses are in basis points (bps). The impulse response calculation is based on the estimated reduced-form model (8). Our model setup implies that the Canadian macro variables could respond to both Canadian and US shocks, but the US macro variables can only respond to US shocks.

In Figure 2, the top and middle three rows show the responses of Canadian macro variables to Canadian and US shocks respectively, and the bottom three rows show the responses of US macro variables to US shocks.

As expected, the Canadian AS shock pushes Canadian inflation almost 12 bps above its steady state, but it soon returns to its original level, given the forward-looking nature of the aggregate supply equation. The Canadian monetary authority increases the shortterm interest rate by 5 bps following the supply shock ${ }^{5}$. The output gap exhibits a hump-shaped decline for a few quarters because of the aggressive reaction of the Canadian monetary authority to inflationary pressures. The Canadian AD shock initially increases the output. The Canadian output gap increases about $40 \mathrm{bps}$, and declines quickly. The response of Canadian inflation is negative but close to zero. The Canadian monetary authority's response to the $\mathrm{AD}$ shock is positive but close to zero. The response of

\footnotetext{
${ }^{5}$ In actual practice, the Canadian monetary authority, the Bank of Canada, only move short-term interest rate in increments of 25 basis points.
} 
Canadian inflation to the MP shock is close to zero. Therefore, a rise in the real interest rate leads to a decline in the aggregate demand. The Canadian output gap initially declines about 20 bps before slowly returning to its equilibrium level.

A US AS shock pushes up US inflation by almost 20 bps, and increases Canadian inflation by almost 15 bps because of the pass through. Inflation rates in both countries return slowly to their equilibrium levels. The initially response of the US output gap is almost zero. The Canadian output gap initially rises to about $10 \mathrm{bps}$, peaks after a few quarters, and declines slowly. Monetary authorities in both countries respond aggressively by raising their short-term interest rates.

A US AD shock not only increases the US output gap, but also widens the Canadian output gap because of the direct pass-through of the AD shocks from the US to Canada. The responses of US and Canadian inflation rates to the US AD shock are positive and close to zero due to the insignificant Phillips curve parameters. Both monetary authorities do not respond initially, and start to raise the short-term interest rates slowly because of the inflation pressure.

A US MP shock increases output gaps in both countries because of the positive estimated parameter of the real interest rate in the US AD equation. The MP shock also increases inflation in both countries, but the impact is very small and close to zero. The Canadian short-term interest rate also rises following the US MP shock.

\subsubsection{Yield Levels}

From the bond yield equation (12), the state variables $X_{t}$ explains all yields dynamics in both countries. To understand the role of each variable in $X_{t}$, we compute the variance decomposition from the model. In addition, the variation in each long yield can be decomposed into two components, one corresponding to the expected movement of future short-term interest rates under the assumption of the Expectations Hypothesis (EH), and 
the other one corresponding to the variation in the embedded risk premium (RP). Since both components are affine functions of $X_{t}$, we can implement the variance decomposition on each component, which gives us a detailed description of the contribution of each variable in $X_{t}$. Following Ang, Dong and Piazzesi (2005), we partition the coefficient $b_{n}^{(i)}$ on $X_{t}$ in equation (12) into an EH component and a RP component:

$$
b_{n}^{(i)}=b_{n}^{(i) E H}+b_{n}^{(i) R P}
$$

where we compute the $b_{n}^{(i) E H}$ bond pricing coefficient by setting $\lambda_{1}^{(i)}=0$. Since yields are given by $y_{t}^{(i, n)}=a_{n}^{(i)}+b_{n}^{(i) \mathrm{T}} X_{t}$, we have

$$
y_{t+h}^{(i, n)}=a_{n}^{(i)}+b_{n}^{(i) E H \mathrm{~T}} X_{t+h}+b_{n}^{(i) R P \mathrm{~T}} X_{t+h}
$$

Let $\Omega^{F, h}$ represent the forecast variance of the state variable $X_{t}$ at horizon $h$. The forecast variance of the $n$-period yield at horizon $h$ is given by

$$
\operatorname{Var}\left(y_{t+h}^{n}\right)=b_{n}^{(i) \mathrm{T}} \Omega^{F, h} b_{n}^{(i)}=b_{n}^{(i) E H \mathrm{~T}} \Omega^{F, h} b_{n}^{(i) E H}+b_{n}^{(i) R P \mathrm{~T}} \Omega^{F, h} b_{n}^{(i) R P}+2 b_{n}^{(i) E H \mathrm{~T}} \Omega^{F, h} b_{n}^{(i) R P},
$$

where the first term corresponds to the $\mathrm{EH}$ component, the second term corresponds to the RP component, and the third component is the covariance between the two components.

Table 3 reports the variance decompositions of both Canadian and US yields and their corresponding components at forecast horizons of 1 quarter, 4 quarters, and 100 quarters. For Canadian yields at the 1-quarter forecast horizon, the Canadian MP shock explains almost all the variations across maturities. However, its contribution to the variation in the 1-year yield mainly comes from the EH component, and its contribution 
to long yields mainly comes from the RP component. At the 4-quarter horizon, the Canadian MP shock is still the dominate factor in explaining over $70 \%$ of variations in Canadian yields. Nevertheless, the US AS shock contributes over $10 \%$ of the yield variations. The unconditional variance decomposition of yield levels shows that both US AS and AD shocks contribute over $50 \%$ of the yield variations, while the remaining variations are mainly explained by the Canadian MP shock. In addition, the US AS and AD shocks dominate other macro shocks in explaining over $60 \%$ of the variations of the EH components of Canadian short and medium yields. The results show that the US macro shocks play important roles in explaining the Canadian yield dynamics.

For US yields, the US monetary policy shock dominate other shocks in explaining over $70 \%$ of yield variations across maturities and at various horizons. However, the US AS shock explains over $20 \%$ of unconditional yield variations. The US variance decomposition results are consistent with the findings of Ang and Piazzesi (2003).

\subsubsection{Expected Excess Holding Period Returns}

The variance decomposition can also be implemented on the expected excess holding period returns in equation (13), since they are also affine functions of the state variable $X_{t}$. We compute the variance decompositions of the expected excess returns of holding Canadian and US bonds over 1 quarter at forecast horizons of 1 quarter, 4 quarters, and 100 quarters. The results are presented in Table 4.

By definition, time-varying expected excess returns must be due only to time-varying risk premia. Therefore, the total and pure risk premia variations are identical. For Canadian bonds, the Canadian MP shock contributes about $40 \%$ of variations in the expected excess holding period returns across maturities and at various horizons. In addition, the US AS shock explains over $40 \%$ of the variations at the 1-quarter horizon. Its explanatory power declines to around $35 \%$ at the 4 -quarter horizon, and $28 \%$ unconditionally. In 
addition, the US AD and MP shocks explain about $12 \%$ of the variations at the 1-quarter horizon, and about $20 \%$ unconditionally. Together, the US macro shocks explain at least $50 \%$ of the variations in the expected excess holding period returns of Canadian bonds.

For US bonds, the US MP shock explains over $70 \%$ of the expected excess holding period returns of US bonds. The US AS shock explains about $25 \%$ of the variation in the expected excess returns of holding US 1-year and 5-year bonds. Its explanatory power in general declines as bond maturities and forecast horizons increase. However, it is still a significant factor in explaining he expected excess holding period returns of US bonds. These findings are also consistent with Ang and Piazzesi (2003).

\subsubsection{Exchange Rate Dynamics and Exchange Risk Premium}

As shown in equation (14), the exchange rate dynamics in our model are dictated by the dynamics of the two SDFs. In addition, the exchange risk premium is linked to the risk premia embedded in bond yields through equation (15). In this section, we compare the model-implied Canada/US exchange rate dynamics and risk premium with those computed from the data.

In the top panel of Figure 3, we plot the model-implied depreciation rate $\widehat{\Delta s}$, which is computed from equation (15), together with the depreciation rate in the data. The correlation between $\widehat{\Delta s}$ and $\Delta s$ is $21.2 \%$. The bottom panel of Figure 3 plots the modelimplied exchange risk premium $\widehat{r e}$, which is computed from equation (16), together with the ex-post exchange risk premium calculated from the data. The correlation between $\widehat{r e}$ and $r e$ is $25.0 \%$. It seems that Canadian and US macro fundamentals help explain the exchange rate dynamics and the exchange risk premium variation. However, the fact that large variations in the Canada/US exchange rate dynamics are unexplained suggests that there are factors affecting the exchange rate not included in the model. Some of these factors may be variables like the current account and commodity prices since Canada is 
an exporter of natural resources.

\section{Conclusion}

This paper estimates the macro dynamics between two countries, and relates it to the dynamics in bond yields and the exchange rate under no-arbitrage conditions. We find that US macro variables contribute to the Canadian yield dynamics because they help not only predict the movement of future Canadian short-term interest rates, but also explain the time-varying bond risk premia. The exchange rate dynamics is linked to the SDFs of both countries in the model. The empirical results seem to suggest that the macro dynamics are also related to the exchange risk premium.

This paper only exploits information from macro variables, such as inflation, the output gap, and the short-term interest rate, to explain the dynamics in bond yields and the exchange rate. It does not include many macro variables which may also contribute to the variations in bond yields and the exchange rate. One of these variables is a fiscal policy variable, such as the government budget deficit, which is an important ingredient of long-term yields (Dai and Philippon (2004)). Another important factor is the energy

price that is relate to the Canada/US exchange rate dynamics (Chen and Rogoff (2003)). Nevertheless, incorporating macro variables into no-arbitrage term structure models helps understand the underlying macro fundamentals that drive the dynamics in bond yields and the exchange rate. 


\section{References}

[1] Ahn, Dong-Hyum, 2004, "Common Factors and Local Factors: Implications for Term Structures and Exchange Rates," Journal of Financial and Quantitative Analysis $39,1,69-102$.

[2] Amin, Kaushik, and Robert A. Jarrow, 1991, "Pricing Foreign Currency Options under Stochastic Interest Rates," Journal of International Money and Finance 10, $310-29$.

[3] Ang, Andrew, and Monica Piazzesi, 2003, "A No-Arbitrage Vector Autoregression of Term Structure Dynamics with Macroeconomic and Latent Variables," Journal of Monetary Economics 50, 4, 745-787.

[4] Ang, Andrew, Sen Dong, and Monica Piazzesi, 2004, "No-arbitrage Taylor rules," Working paper, Columbia University.

[5] Ang, Andrew, Monica Piazzesi, and Min Wei, 2004, "What Does the Yield Curve Tell us about GDP Growth?" Working paper, Columbia University.

[6] Ball, Laurence, 1998, "Policy Rules for Open Economies," NBER working paper 6770 .

[7] Bekaert, Geert, Seonghoon Cho, and Antonio Moreno, 2005, "New-Keynesian Macroeconomics and the Term Structure," Working paper, Columbia University.

[8] Bikbov, Ruslan, and Mikhail Chernov, 2005, "No-Arbitrage Macroeconomic Determinants of the Yield Curve," Working paper, Columbia University.

[9] Bolder, David, Grahame Johnson, and Adam Metzler, 2004, "An Empirical Analysis of the Canadian Term Structure of Zero-Coupon Interest Rates," Bank of Canada Working Paper 2004-48.

[10] Brandt, Michael, John H. Cochrane, and Pedro Santa-Clara, 2006, "International Risk Sharing is Better than You Think, or Exchange Rates are too Smooth?" Journal of Monetary Economics 53, 671-98.

[11] Brandt, Michael, and Pedro Santa-Clara, 2002, "Simulated Likelihood Estimation of Diffusions with an Application to Exchange Rates Dynamics in Incomplete Markets," Journal of Financial Economics 63, 161-210.

[12] Campbell, John and J. Ammer, 1993, "What Moves the Stock and Bond Markets? A Variance Decomposition for Long-Term Asset Returns," Journal of Finance 48, 3-37. 
[13] Chen, Ren-Raw, and Louis Scott, 1993, "Maximum Likelihood Estimation for a Multifactor Equilibrium Model of the Term Structure of Interest Rates," Journal of Fixed Income 3, 14-31.

[14] Chen, Yu-Chin, and Keneth Rogoff, 2003, "Commodity Currencies", Journal of International Economics 60, 133-160.

[15] Cho, Seonghoon, and Antonio Moreno, 2006, "A Small-Sample Study of the NewKeynesian Macro Model," Journal of Money, Credit and Banking 38, 1461-81.

[16] Clarida, Richard, Jordi Galí, and Mark Gertler, 1999, "The Science of Monetary Policy: a New Keynesian Perspective," Journal of Economic Literature 37, 16611707.

[17] Clarida, Richard, Jordi Galí, and Mark Gertler, 2000, "Monetary Policy Rules and Macroeconomic Stability: Evidence and Some Theory," Quarterly Journal of Economics 115, 147-180.

[18] Dai, Qiang, and Thomas Philippon, 2005, "Government Deficits and Interest Rates: A No-Arbitrage Structural VAR Approach," Working paper, New York University.

[19] Dai, Qiang, and Kenneth J. Singleton, 2000, "Specification Analysis of Affine Term Structure Models," Journal of Finance 55, 5, 1943-1978.

[20] Dai, Qiang, and Kenneth J. Singleton, 2002, Expectation Puzzles, Time-Varying Risk Premia, and Affine Models of Term Structure, "Journal of Financial Economics $63,415-441$.

[21] Dewachter, Hans, and Macro Lyrio, 2004, "Macro Factors and the Term Structure of Interest Rates," Working paper.

[22] Diebold, Francis X., Gleen D. Rudebusch, and S. Boragan Aruoba, 2004, "The Macroeconomy and the Yield Curve: a Dynamic Latent Factor Approach," Forthcoming Journal of Econometrics.

[23] Duffee, Gregory R., 2002, "Term Premia and Interest Rate Forecasts in Affine Models," Journal of Finance 57, 405-443.

[24] Duffee, Gregory R., 2002, "Term Structure Estimation without using Latent Factors," Forthcoming Journal of Financial Economics.

[25] Duffie, Darrel, and Rui Kan, 1996, "A Yield-Factor Model of Interest Rates," Mathematical Finance 6, 379-406.

[26] Engel, Charles, 1996, "The Forward Discount Anomaly and the Risk Premium: a Survey of Recent Evidence," Journal of Empirical Finance 3, 123-192. 
[27] Engel, Charles, and Kenneth West, 2006, "Taylor Rules and the DeutschemarkDollar Real Exchange Rate," Journal of Money, Credit and Banking 38, 1175-1194.

[28] Estrella, Arturo, and Gikas A. Hardouvelis, 1991, "The Term Structure as a Predictor of Real Economy Activity," Journal of Finance 46, 555-76.

[29] Estrella, Arturo, and Frederic S. Miskin, 1997, "The Predictive Power of the Term Structure of Interest Rates in Europe and the United States: Implications for the European Central Bank," European Economics Review 41, 1375-401.

[30] Evans, Charles L., and Marshall, David, 2001, "Economic Determinants of the Nominal Treasury Yield Curve," Working paper, Federal Reserve Bank of Chicago.

[31] Fuhrer, Jeffrey C., 2000, "Habit Formation in Consumption and its Implications for Monetary-Policy Models," American Economic Review 90, 367-89.

[32] Galí, Jordi, and Mark Gertler, 1999, "Inflation Dynamics: a Structural Econometric Analysis," Journal of Monetary Economics 44, 195-222.

[33] Gallmeyer, Michael, Burton Hollifield, and Stanley Zin, 2005, "Taylor Rules, McCallum Rules, and the Term Strucutre of Interest Rates," Forthcoming Journal of Monetary Economics.

[34] Garcia, René and Richard Luger, 2005, "The Canadian Macroeconomy and the Yield Cuve: an Equilibrium-based Approach," Forthcoming The Canadian Journal of Economics.

[35] Giordani, Paul, 2004, "Evaluating New-Keynesian Models of a Small Open Economy," Oxford Bulletin of Economics and Statistics 66, 713-733.

[36] Graveline, Jeremy J., 2006, "Exchange Rate Volatility and the Forward Premium Anomaly," Working paper, Stanford University.

[37] Gurkaynak, Refet S., Brain P. Sack, and Jonathan H. Wright, 2006, "The U.S. Treasury Yield Curve: 1961 to Present, " Federal Reserve Board Working Paper 2006-28.

[38] Han, Bing, and Peter Hammond, 2003, "Affine Models of the Joint Dynamics of Excange Rates and Interest Rates," Working paper, University of Calgary.

[39] Hördahl, Peter, Oreste Tristani, and David Vestin, 2004, "A Joint Econometric Model of Macroeconomic and Term Structure Dynamics," Forthcoming Journal of Econometrics.

[40] Lane, P. R. and Ganelli, G. 2003, Dynamic General Equilibrium Analysis: the Open Economy Dimension. in Altug S., Chaddha J. and Nolan C. (eds), Dynamic Macroeconomic Analysis, Cambridge University Press, cambridge, pp, 308-334. 
[41] Leeper, Eric M., and Tao Zha, 2000, "Assessing Simple Policy Rules: a View from a Complete Macro Model, “ Federal Reserve Bank of Atlanta Working Paper 19.

[42] Leippold, Markus, and Liuren Wu, 2004, "Design and Estimation of Multi-Currency Quadratic Models," Working paper, University of Zurich.

[43] Litterman, R. and J. Scheinkman, 1991, "Common Factors Affecting Bond Returns," Journal of Fixed Income 1, 54-61.

[44] Lucas, Robert E. 1998, "Asset Prices in an Exchange Economy," Econometrica 46, 1426-1446.

[45] McCallum, Bennett T., 1998, "Solutions to Linear Rational Expectations Models: a Compact Exposition," Economics letters 6, 143-147.

[46] Nielsen, Lars T., and Jesús Saá-Requejo, 1993, "Exchange Rate and Term Structure Dynamics and the Pricing of Derivative Securities," Working paper, INSEAD.

[47] Pearson, Neil D., and Tony-Shen Sun, 1994, "Exploiting the Conditional Density Function in Estimating the Term Structure: an Application to the Cox, Ingersoll and Ross Model," Journal of Finance 49, 1279-1304.

[48] Rudebusch, Glenn D., and Tao Wu, 2003, "A Macro-Fiance Model of the Term Structure, Monetary Policy, and the Economy," Federal Reserve Bank of San Francisco, Working Paper 03-17.

[49] Sen Dong, 2006, "Macro Variables Do Drive Exchange Rate Movements: Evidence from a No-Arbitrage Model," Working paper, Columbia University.

[50] Svensson, Lars E. O., 2000, "Open Economy Inflation Targeting," Journal of International Economics 50, 155-183.

[51] Taylor, John B., 1999, “A Historical Analysis of Monetary Policy Rules,” in John B. Taylor, Ed. Monetary Policy Rules, University of Chicago Press, 319-341.

[52] Wu, Tao, 2002, "Macro Factors and the Affine Term Structure of Interest Rates," Forthcoming Journal of Money, Credit and Banking. 


\section{Table 1: Parameter Estimates}

Panel A: Macro Dynamics

\begin{tabular}{|c|c|c|c|c|c|c|c|c|c|}
\hline \multirow[b]{2}{*}{ AS } & \multicolumn{5}{|c|}{ Canada } & \multicolumn{4}{|c|}{ US } \\
\hline & $\begin{array}{r}\alpha_{\pi} \\
0.689 \\
(0.22)\end{array}$ & $\begin{array}{c}\alpha_{g} \\
-0.000 \\
(0.05)\end{array}$ & $\begin{array}{c}\alpha_{\pi_{t}^{*}} \\
-0.188 \\
(0.06)\end{array}$ & $\begin{array}{c}\alpha_{\pi_{t-1}^{*}} \\
0.212 \\
(0.09)\end{array}$ & $\begin{array}{c}\sigma_{\varepsilon_{\pi}} \\
0.002\end{array}$ & $\begin{array}{r}\alpha_{\pi}^{*} \\
0.545 \\
(0.19)\end{array}$ & $\begin{array}{r}\alpha_{g}^{*} \\
0.000 \\
(0.03)\end{array}$ & & $\begin{array}{c}\sigma_{\varepsilon_{\pi}^{*}} \\
0.001\end{array}$ \\
\hline $\mathrm{AD}$ & $\beta_{g}$ & $\beta_{r}$ & $\beta_{g_{t}^{*}}$ & $\beta_{g_{t-1}^{*}}$ & $\sigma_{\varepsilon_{g}}$ & $\beta_{g}^{*}$ & $\beta_{r}^{*}$ & & $\sigma_{\varepsilon_{g}^{*}}$ \\
\hline & $\begin{array}{c}0.492 \\
(0.20)\end{array}$ & $\begin{array}{c}-0.048 \\
(0.02)\end{array}$ & $\begin{array}{c}0.305 \\
(0.13)\end{array}$ & $\begin{array}{c}-0.273 \\
(0.08)\end{array}$ & 0.003 & $\begin{array}{c}0.526 \\
(0.17)\end{array}$ & $\begin{array}{c}0.012 \\
(0.03)\end{array}$ & & 0.004 \\
\hline MP & $\begin{array}{r}\gamma_{\pi} \\
1.489 \\
(0.43)\end{array}$ & $\begin{array}{c}\gamma_{g} \\
0.095 \\
(0.05)\end{array}$ & $\begin{array}{r}\rho \\
0.832 \\
(0.25)\end{array}$ & & $\begin{array}{c}\sigma_{\varepsilon_{r}} \\
0.003\end{array}$ & $\begin{array}{r}\gamma_{\pi}^{*} \\
1.086 \\
(0.37)\end{array}$ & $\begin{array}{r}\gamma_{g}^{*} \\
0.040 \\
(0.02)\end{array}$ & $\begin{array}{r}\rho^{*} \\
0.806 \\
(0.19)\end{array}$ & $\begin{array}{c}\sigma_{\varepsilon_{r}^{*}} \\
0.003\end{array}$ \\
\hline
\end{tabular}

Panel B: Market Prices of Risk

\begin{tabular}{|c|c|c|}
\hline Canada & & $\lambda_{0}$ \\
\hline & $\pi$ & $\begin{array}{c}0.07 \\
(0.21)\end{array}$ \\
\hline & $g$ & $\begin{array}{c}0.01 \\
(0.19)\end{array}$ \\
\hline & $r$ & $\begin{array}{c}0.02 \\
(0.06)\end{array}$ \\
\hline & $\pi^{*}$ & $\begin{array}{c}-0.04 \\
(0.18)\end{array}$ \\
\hline & $g^{*}$ & $\begin{array}{l}-0.41 \\
(0.28)\end{array}$ \\
\hline & $r^{*}$ & $\begin{array}{c}1.02 \\
(0.67)\end{array}$ \\
\hline US & & $\lambda_{0}^{*}$ \\
\hline & $\pi^{*}$ & $\begin{array}{c}0.61 \\
(0.52)\end{array}$ \\
\hline & $g^{*}$ & $\begin{array}{l}-0.95 \\
(0.80)\end{array}$ \\
\hline & $r^{*}$ & $\begin{array}{c}-0.18 \\
(0.28)\end{array}$ \\
\hline
\end{tabular}

\begin{tabular}{cccccc}
\multicolumn{7}{c}{$\lambda_{1}$} \\
\hline$\pi$ & $g$ & $r$ & $\pi^{*}$ & $g^{*}$ & $r^{*}$ \\
-4.57 & -2.23 & -9.89 & 145.32 & 13.09 & -47.25 \\
$(2.03)$ & $(1.82)$ & $(5.08)$ & $(6.08)$ & $(3.88)$ & $(8.41)$ \\
8.47 & 2.05 & 20.67 & 91.86 & 8.83 & -62.50 \\
$(2.45)$ & $(0.70)$ & $(4.54)$ & $(9.55)$ & $(1.73)$ & $(6.01)$ \\
-2.79 & 7.75 & -48.72 & 14.35 & -2.11 & 40.83 \\
$(1.91)$ & $(1.48)$ & $(6.30)$ & $(3.51)$ & $(1.02)$ & $(5.92)$ \\
& & & 164.18 & 16.67 & -64.30 \\
& & & $(7.01)$ & $(3.31)$ & $(6.22)$ \\
& & & 22.17 & 11.03 & 13.44 \\
& & & $(4.22)$ & $(3.00)$ & $(4.88)$ \\
& & & -57.74 & -22.74 & 66.81 \\
& & & $(11.94)$ & $(3.89)$ & $(7.73)$
\end{tabular}

This table reports parameter estimates for the model. Panel A reports parameter estimates for the macro dynamics for both countries. Panel B reports estimates of the market prices of risk. The Newy-West 3-lag standard errors are calculated and reported in the parathesis. 
Table 2: Fit of the Model

Panel A: Moments of Macro Variables

\begin{tabular}{|c|c|c|c|c|c|c|c|c|c|}
\hline \multirow{3}{*}{\multicolumn{2}{|c|}{ Means \% }} & & $\pi$ & $g$ & $r$ & $\pi^{*}$ & $g^{*}$ & $r^{*}$ & \\
\hline & & Data & 0.831 & 0.000 & 1.831 & 0.772 & 0.008 & 1.462 & \\
\hline & & & $(0.110)$ & $(0.078)$ & (0.107) & $(0.093)$ & $(0.079)$ & $(0.094)$ & \\
\hline \multirow{3}{*}{\multicolumn{2}{|c|}{ Stdev \% }} & Model & 0.847 & 0.012 & 1.855 & 0.784 & 0.035 & 1.486 & \\
\hline & & Data & 0.619 & 3.056 & 0.994 & 0.482 & 2.020 & 0.801 & \\
\hline & & & $(0.094)$ & $(0.235)$ & $(0.095)$ & $(0.086)$ & $(0.206)$ & $(0.088)$ & \\
\hline \multirow{4}{*}{\multicolumn{2}{|c|}{ Autocorr. }} & Model & 0.537 & 3.005 & 0.952 & 0.431 & 1.887 & 0.741 & \\
\hline & & Data & 0.818 & 0.969 & 0.956 & 0.867 & 0.936 & 0.916 & \\
\hline & & & $(0.057)$ & $(0.071)$ & $(0.033)$ & $(0.063)$ & $(0.058)$ & $(0.044)$ & \\
\hline & & Model & 0.919 & 0.968 & 0.961 & 0.879 & 0.936 & 0.931 & \\
\hline & & $\begin{array}{c}\text { Panel } \\
n=2\end{array}$ & $\begin{array}{l}\text { Mom } \\
n=4\end{array}$ & its of & $\begin{array}{l}\text { adian } \\
n=12\end{array}$ & $\begin{array}{l}1 \mathbf{d} \text { US } \\
n=20\end{array}$ & $\begin{array}{l}\text { Yields } \\
n=28\end{array}$ & $n=40$ & $n=60$ \\
\hline \multirow{3}{*}{$\begin{array}{c}\text { Canada } \\
\text { Means \% }\end{array}$} & Do & & & & & & 20 & 2097 & \\
\hline & Dald & $(0.10$ & $(0.107)$ & $\begin{array}{l}1.001 \\
(0.107)\end{array}$ & $(0.106)$ & $(0.106)$ & $(0.105)$ & $(0.105)$ & $(0.104)$ \\
\hline & Mode & 1.82 & 1.839 & 1.873 & 1.911 & 1.983 & 2.045 & 2.118 & 2.179 \\
\hline \multirow[t]{3}{*}{ Stdev \% } & Data & 0.95 & 0.907 & 0.852 & 0.816 & 0.777 & 0.771 & 0.756 & 0.772 \\
\hline & & $(0.090)$ & $(0.081)$ & $(0.080)$ & $(0.080)$ & $(0.078)$ & $(0.077)$ & $(0.077)$ & $(0.075)$ \\
\hline & Model & 0.96 & 0.925 & 0.857 & 0.809 & 0.751 & 0.722 & 0.706 & 0.710 \\
\hline \multirow[t]{3}{*}{ Autocorr. } & Data & 0.961 & 0.959 & 0.957 & 0.965 & 0.965 & 0.972 & 0.975 & 0.978 \\
\hline & & $(0.033)$ & $(0.032)$ & $(0.032)$ & $(0.031)$ & $(0.030)$ & $(0.028)$ & $(0.028)$ & $(0.027)$ \\
\hline & Model & 0.957 & 0.958 & 0.959 & 0.959 & 0.961 & 0.962 & 0.963 & 0.964 \\
\hline $\mathrm{U}$ & & & & & & & & & \\
\hline \multirow[t]{3}{*}{ Means \% } & Data & 1.49 & 1.613 & 1.687 & 1.739 & 1.814 & 1.868 & 1.928 & 1.990 \\
\hline & & $(0.1$ & $(0.106)$ & $(0.105)$ & $(0.104)$ & $(0.104)$ & $(0.104)$ & $(0.103)$ & $(0.101)$ \\
\hline & Mod & 1.506 & 1.578 & 1.679 & 1.747 & 1.830 & 1.875 & 1.909 & 1.992 \\
\hline \multirow[t]{3}{*}{ Stdev \% } & Data & 0.79 & 0.822 & 0.799 & 0.775 & 0.735 & 0.705 & 0.671 & 0.641 \\
\hline & & $(0.08$ & $(0.076)$ & $(0.076)$ & $(0.073)$ & $(0.072)$ & $(0.072)$ & $(0.070)$ & 7) \\
\hline & M & 0.79 & 0.791 & 0.774 & 0.755 & 0.714 & 0.673 & 0.616 & 0.541 \\
\hline \multirow[t]{3}{*}{ Autocorr. } & Data & 0.928 & 0.945 & 0.953 & 0.958 & 0.964 & 0.967 & 0.968 & 0.969 \\
\hline & & $(0.0$ & $(0.031)$ & $(0.031)$ & (0.030) & $(0.030)$ & $(0.028)$ & $(0.026)$ & $(0.026)$ \\
\hline & Model & 0.915 & 0.914 & 0.913 & 0.913 & 0.912 & 0.912 & 0.912 & 0.921 \\
\hline
\end{tabular}

Panel C: Moments of Changes in log Excange Rate

\begin{tabular}{|c|c|c|c|c|c|c|}
\hline \multirow[b]{3}{*}{$\ln \left(S_{t+1} / S_{t}\right)$} & \multicolumn{2}{|c|}{ Means \% } & \multicolumn{2}{|c|}{ Stdev \% } & \multicolumn{2}{|c|}{ Autocorr. } \\
\hline & Data & Model & Data & Model & Data & Model \\
\hline & $\begin{array}{c}-0.063 \\
(0.019)\end{array}$ & -0.041 & $\begin{array}{c}2.654 \\
(0.234)\end{array}$ & 2.629 & $\begin{array}{c}0.033 \\
(0.010)\end{array}$ & 0.570 \\
\hline
\end{tabular}




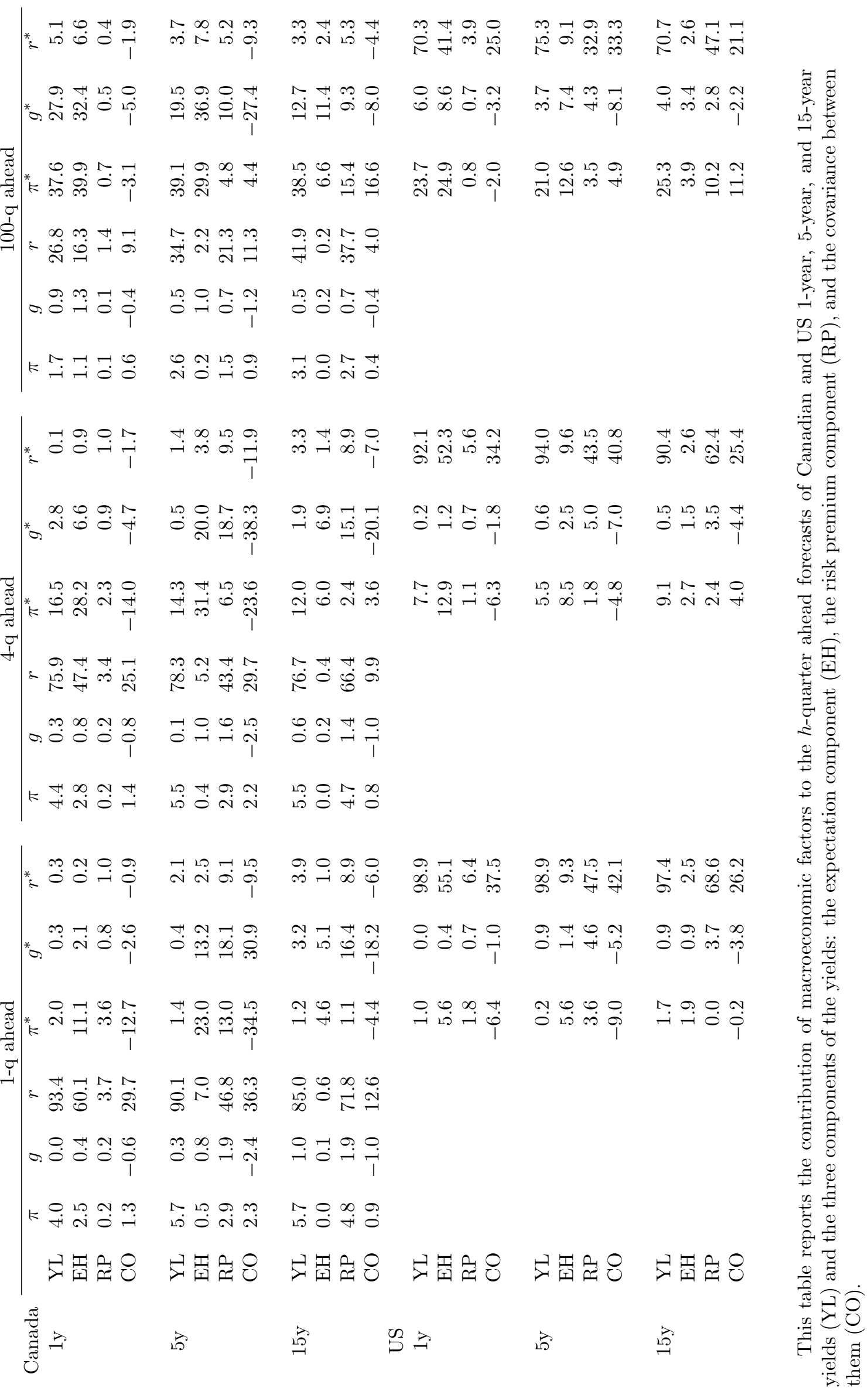


Table 4: Variance Decomposition of Expected Excess Holding Period Returns

\begin{tabular}{|c|c|c|c|c|c|c|c|}
\hline \multirow[b]{2}{*}{ Canada } & \multirow[b]{2}{*}{ maturity } & $\pi$ & $g$ & $r$ & $\pi^{*}$ & $g^{*}$ & $r^{*}$ \\
\hline & & 1.5 & 2.4 & 35.8 & 44.5 & 7.8 & 8.0 \\
\hline \multirow[t]{2}{*}{ 1-q ahead } & $5 y$ & 1.8 & 2.2 & 38.0 & 45.0 & 8.9 & 4.1 \\
\hline & $15 y$ & 2.2 & 2.2 & 42.7 & 41.5 & 8.3 & 3.1 \\
\hline \multirow{3}{*}{ 4-q ahead } & $1 \mathrm{y}$ & 2.1 & 2.5 & 39.3 & 35.5 & 10.8 & 9.8 \\
\hline & $5 y$ & 2.4 & 2.2 & 42.6 & 34.9 & 12.1 & 5.8 \\
\hline & $15 y$ & 2.9 & 2.3 & 48.3 & 30.9 & 11.1 & 4.5 \\
\hline \multirow{3}{*}{ 100-q ahead } & $1 y$ & 2.4 & 2.3 & 41.2 & 27.8 & 14.6 & 11.8 \\
\hline & $5 y$ & 2.7 & 2.0 & 44.4 & 28.2 & 15.2 & 7.5 \\
\hline & $15 y$ & 3.2 & 2.0 & 49.7 & 26.5 & 12.9 & 5.8 \\
\hline US & & & & & & & 600 \\
\hline \multirow{2}{*}{ 1-q ahead } & $\begin{array}{l}1 \mathrm{y} \\
5 \mathrm{y}\end{array}$ & & & & 24.2 & $\begin{array}{l}5.9 \\
34\end{array}$ & $\begin{array}{l}69.9 \\
71.4\end{array}$ \\
\hline & $15 \mathrm{y}$ & & & & 17.5 & 3.1 & 79.4 \\
\hline \multirow{3}{*}{ 4-q ahead } & $1 \mathrm{y}$ & & & & 18.7 & 8.0 & 73.3 \\
\hline & $5 y$ & & & & 19.5 & 4.6 & 75.9 \\
\hline & $15 y$ & & & & 12.1 & 3.9 & 84.1 \\
\hline \multirow{3}{*}{ 100-q ahead } & $1 \mathrm{y}$ & & & & 17.0 & 10.4 & 72.6 \\
\hline & $5 y$ & & & & 18.1 & 5.5 & 76.4 \\
\hline & $15 \mathrm{y}$ & & & & 13.0 & 4.2 & 82.8 \\
\hline
\end{tabular}

This table reports the contribution of macroeconomic factors to the $h$-quarter ahead forecasts of Canadian and US expected excess holding period (1-quarter) returns of 1-year, 5-year, and 15-year zero coupon bonds. 
Figure 1: Model-Implied Macro Variables and Shocks
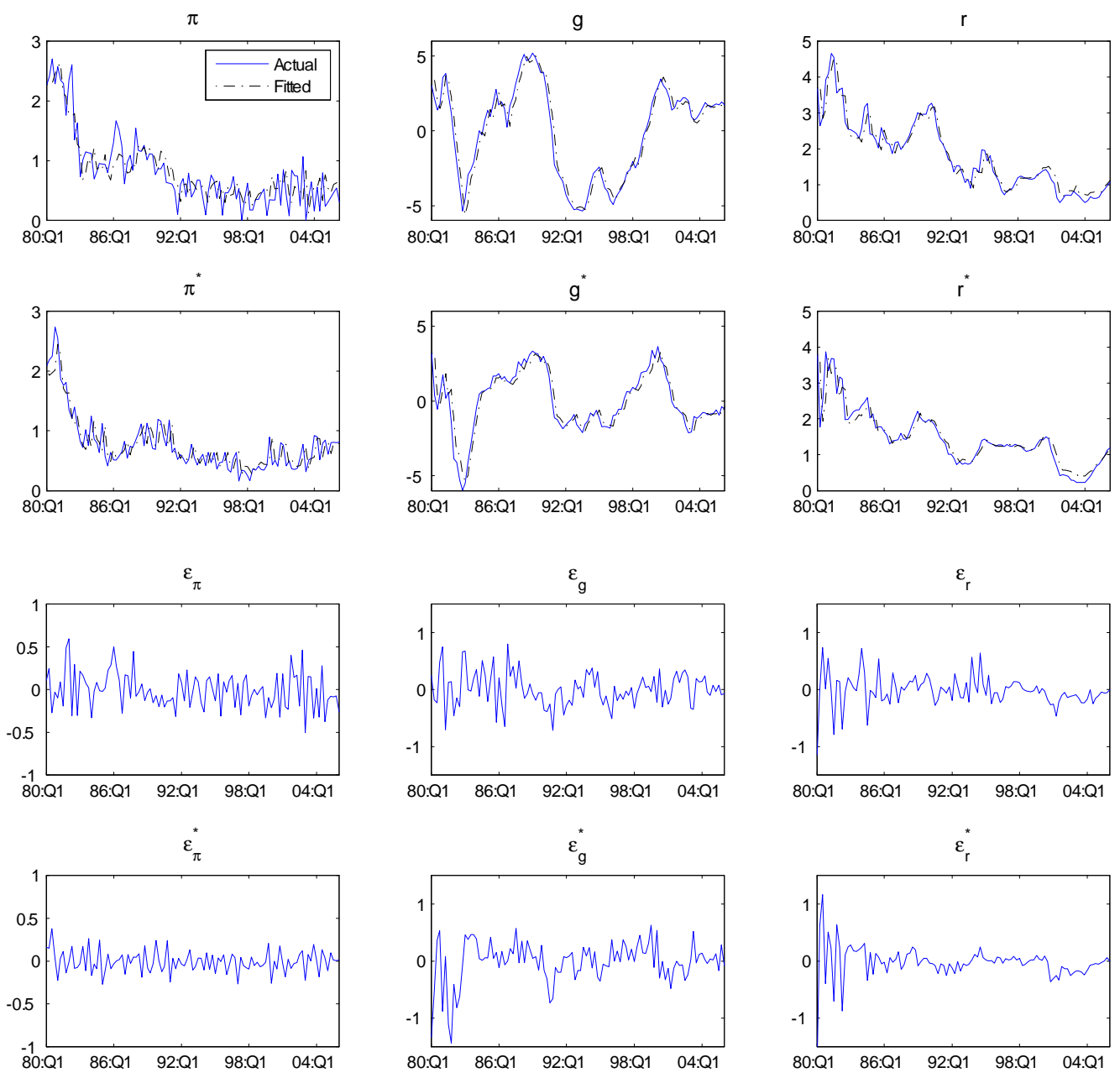

The top six graphs show the model-implied values for Canadian and US inflation, output gaps, and short-term interest rates associated with the ML estimation of the macro model. The bottom six graphs show the estimated Canadian and US macro shocks. The sample period is 1980:Q1 to 2006:Q2. 
Figure 2: Impulse Response Functions of Macro Variables
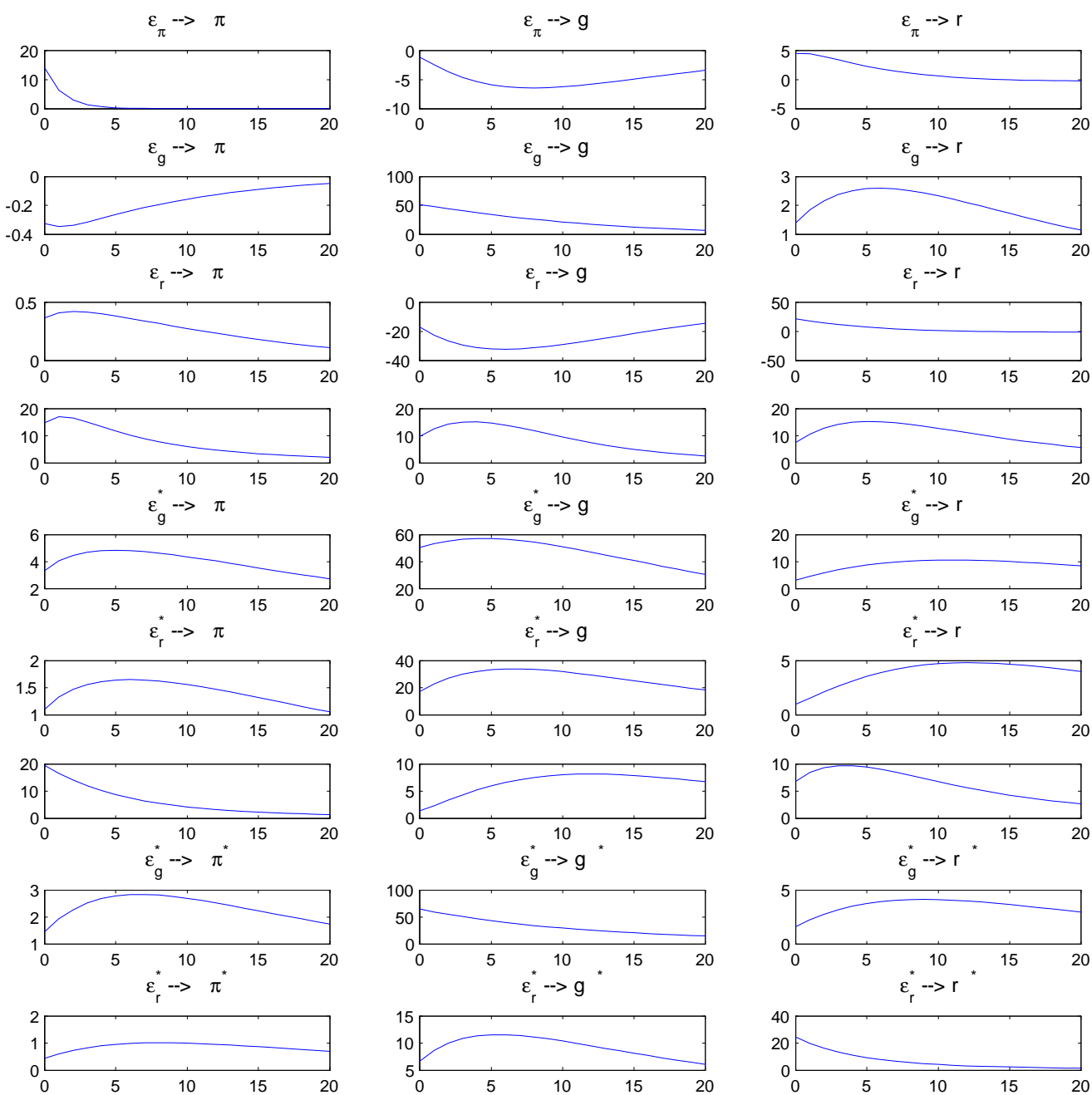

The graphs show the model-implied impulse responses (in basis points) of Canadian and US macro variables to a one standard deviation increase to macro shocks. The top three rows show the responses of Canadian macro variables to Canadian shocks. The middle three rows show the responses of Canadian macro variables to US shocks. The bottom three rows show the responses of US macro variables to US shocks. 
Figure 3: Data and Model-Implied Exchange Rate
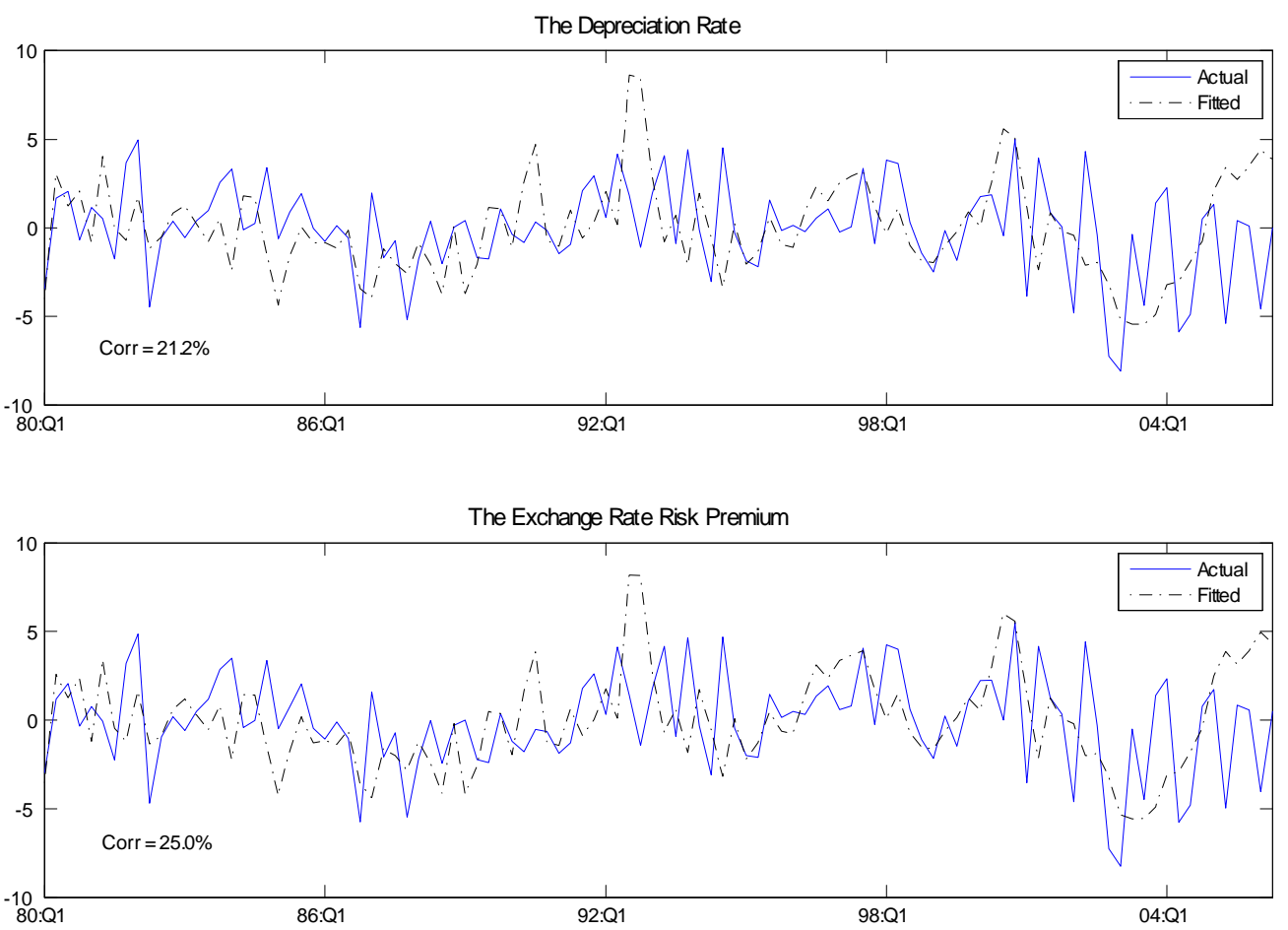

The top graph plots the observed and model-implied depreciation rate of the exchange rate between Canada and the US. The bottom graph plots the observed and model-implied exchange rate risk premium. The sample period is 1980:Q1 to 2006:Q2. 